\title{
PEMANFAATAN AUGMENTED REALITY UNTUK MELATIH KETERAMPILAN BERPIKIR ABAD 21 DI PEMBELAJARAN IPA
}

\author{
Yonatan Vari' ${ }^{1}$ Bramastia $^{2}$ \\ 1,2,3 Program Studi S2 Pendidikan Sains, Fakultas Keguruan dan Ilmu Pendidikan, Universitas Sebelas Maret \\ Surakarta, 57126, Indonesia \\ Email: 1'yonatanvari@student.uns.ac.id; ${ }^{2}$ bramastia@staff.uns.ac.id
}

Diajukan: 8 Agustus 2021; Diterima: 25 September 2021; Diterbitkan: 30 Oktober 2021

\begin{abstract}
Abstrak: Era Revolusi 4.0 ditandai dengan perkembangan internet dan teknologi digital. Era Revolusi 4.0 diyakini akan berpengaruh terhadap perubahan pembelajaran Sains yang mampu melatih keterampilan berpikir abad 21. Pembelajaran Abad 21 menekankan subjek pembelajaran terhadap siswa pada keterampilan dalam menggunakan Media, Informasi dan Teknologi; Keterampilan berpikir dan berinovasi. Augmented Reality merupakan inovasi teknologi yang sedang berkembang dan dimanfaatkan pada pembelajaran IPA oleh beberapa peneliti untuk melatih keterampilan Abad 21. Metode Penelitian merupakan penelitian studi literatur dengan menelaah sumber baik dari buku maupun jurnal terkait dengan Augmented Reality dan Keterampilan Abad 21Penelitian yang dilakukan beberapa peneliti saat ini yaitu memanfaatkan Augmented Reality untuk melatih keterampilan berpikir yang meliputi keterampilan berpikir kritis, keterampilan berpikir abstrak, dan kemampuan berpikir kreatif. Penelitian yang ada menemukan bahwa Augmented Reality dapat melatih keterampilan berpikir siswa pada pembelajaran IPA.
\end{abstract}

Kata Kunci : Augmented Reality, Pembelajaran Abad 21, Keterampilan Berpikir

Abstract: The Revolutionary Era 4.0 was marked by the development of the internet and digital technology. The Revolutionary Era 4.0 is believed to have an effect on changes in science learning that is able to train 21 st century thinking skills. 21st Century Learning emphasizes the subject of learning for students on skills in using Media, Information and Technology; Thinking and innovation skills. Augmented Reality is a technological innovation that is being developed and is being used in science learning by several researchers to train 21st Century skills. The Research Method is a literature study by reviewing sources both from books and journals related to Augmented Reality and 21st Century Skills Research conducted by several researchers at this time namely utilizing Augmented Reality to train thinking skills which include critical thinking skills, abstract thinking skills, and creative thinking skills. Existing research finds that Augmented Reality can train students' thinking skills in science learning.

Keywords: Augmented Reality, 21st Century Learning, Thinking Skills

\section{Pendahuluan}

Era Revolusi 4.0 ditandai dengan perkembangan internet dan teknologi digital yang pesat menyebabkan segala hal menjadi tanpa batas. Era Revolusi 4.0 diyakini akan berpengaruh terhadap perubahan di banyak bidang, termasuk pembelajaran IPA sehingga menimbulkan banyak tantangan yang muncul dalam pembelajaran. Pembelajaran yang ada saat ini harus merujuk pada empat karakter belajar abad 21, yaitu berpikir kritis dan pemecahan masalah, kreatif dan inovasi, kolaborasi, dan komunikasi. Pembelajaran abad 21 membutuhkan pembelajaran yang terbuka serta adaptif dengan perkembangan teknologi saat ini.

Salah satu perkembangan teknologi yang cukup banyak digunakan oleh banyak kalangan di berbagai bidang saat ini adalah Augmented Reality. Augmented Reality (AR) adalah teknologi di mana dunia nyata ditambah dengan konten yang dihasilkan komputer seperti teks, gambar, dan video. Augmented Reality memiliki tiga karakteristik utama: kombinasi dunia nyata dan elemen virtual, interaksi dengan pengguna secara realtime, dan terdaftar dalam ruang 3D. Augmented Reality menawarkan kebebasan dan pengalaman baru kepada pengguna dengan memungkinkan mereka untuk memindahkan gambar virtual 3D dan melihatnya dari titik mana pun sama seperti aslinya.

Teknologi Augmented Reality dalam proses pembelajaran dapat memberikan sebuah pengalaman belajar yang baru serta melatih keterampilan dan pengetahuan di abad 21 . 
Pengembangan proses pembelajaran dengan memanfaatkan perkembangan teknologi yang ada saat ini perlu menyesuaikan dengan karakter pembelajaran abad 21. Kenyataan bahwa pembalajaran abad 21 yang masih belum terlaksana dengan maksimal dan cukup baik di sekolah, mendorong beberapa penelitian yang mengintegrasikan teknologi Augmented Reality ke dalam pembelajaran IPA. Pemanfaataan Augmented Reality sebagai salah satu teknologi saat ini untuk melatih Keterampilan Berpikir Abad 21.

Keterampilan berpikir abad 21 merupakan keterampilan yang perlu dimiliki oleh siswa saat ini dalam rangka mengikuti tuntutan zaman saat ini. Tujuan dari makalah ilmiah ini adalah untuk menyajikan gambaran dari penelitian sebelumnya yang telah mengintegrasikan teknologi AR untuk tujuan pembelajaran. Ini mencakup jurnal penelitian Augmented Reality pada Pembelajaran Sains selama 5 tahun terakhir (2016-2021). Paper yang ada menjelaskan rumusan masalah berikut

1. Apakah media pembelajaran Augmented Reality dapat dimanfaatkan untuk melatih keterampilan berpikir Abad 21?

2. Bagaimana pemanfaatan media pembelajaran Augmented Reality untuk melatih keterampilan berpikir Abad 21?

\section{Metode}

Metode Penelitian merupakan penelitian studi literatur dengan menelaah sumber baik dari buku maupun jurnal terkait dengan Augmented Reality dan Keterampilan Abad 21. Hasil dari berbagai telaah ini yang akan digunakan untuk mengetahui pemanfaatan Augmented Reality untuk melatih keterampilan abad 21

\section{Hasil Penelitian dan Pembahasan}

\section{A. Augmented Reality}

Augmented Reality merupakan peggabungan atau penambahan objek virtual 3D ke dalam suatu layar perangkat dengan objek nyata yang dapat berinteraksi secara realtime, dan dibuat dengan menggunakan computer (Azzuma R, 1997) (Afissunani, 2014). Augmented Reality bertujuan untuk mengembangkan teknologi yang memberikan pengalaman untuk mengamati objek virtual yang diproyeksikan pada dunia nyata.
Teknologi $A R$ dapat menampilkan informasi tertentu kedalam dunia maya dan menampilkannya di dunia nyata dengan bantuan perlengkapan seperti webcam, komputer, smartphone Android, maupun kacamata khusus (Efendi 2013). Berdasarkan uraian pendapat diatas Augmented Reality akan membantu dalam menyampaikan suatu informasi kepada pengguna dengan cara memproyeksikan informasi yang ada (objek 2D atau 3D) ke dalam dunia nyata.

Teknologi Augmented Reality dimanfaatkan dalam berbagai bidang salah satunya dalam proses pembelajaran. Pemanfaatan Augmented Reality dalam pembelajaran yaitu untuk menyampaikan materi atau informasi dalam bentuk animasi gambar. Pemanfaatan teknologi Augmented Reality dalam proses pembelajaran memiliki kelebihan serta kekurangan. Ilmawan Mustaqim et.al (2017) mengemukakan bahwa Augmented Reality memiliki beberapa kelebihan sebagai berikut :

1) Lebih interaktif,

2) Efektif dalam penggunaan,

3) Dapat diimplementasikan secara luas dalam berbagai media,

4) Modeling obyek yang yang sederhana, karena hanya menampilkan beberapa obyek,

5) Pembuatan yang tidak memakan terlalu banyak biaya,

6) Mudah untuk dioperasikan.

Sedangkan kekurangan dari Augmented Reality menurut Ilmawan Mustaqim et.al (2017) yaitu meliputi beberapa hal berikut:

1) Sensitif dengan perubahan sudut pandang,

2) Pembuat belum terlalu banyak,

3) Membutuhkan banyak memori pada peralatan yang dipasang.

Berdasarkan uraian diatas Augmented

Reality dapat dimanfaatkan dalam proses pembelajaran karena mendukung pembelajaran menjadi lebih interaktif salah satunya Pembelajaran IPA. Augmented Reality sebagai salah satu teknologi yang berkembangan pada saat ini, para pengajar dituntut untuk dapat menyesuaikan diri dengan perkembangan teknologi saat ini. 


\section{B. Keterampilan Abad 21}

Abad ke-21 ditandai dengan masifnya perkembangan teknologi, sehingga ilmu pengetahuan menjadi pondasi penting dalampembangunan nasional (Kemendikbud, 2016). Pembelajaran di abad ke-21 memiliki paradigma yang lebih menuntut kemampuan berpikir kritis, menemukan relasi antara teori di kelas dengan dunia nyata, mahir teknologi informasi, berinteraksi dan bekerja sama (Afriyanti dkk., 2018). Berdasarkan uraian diatas maka, Pembelajaran yang ada di sekolah saat ini diharapkan mampu menghasilkan lulusan yang memiliki keterampilan untuk berpikir kritis dan berkerjasama serta menguasaia teknologi di abad ke-21.

Keterampilan Abad 21 merupakan keterampilan penting yang harus dikuasai oleh setiap orang agar berhasil dalam menghadapi tantangan, permasalahan, kehidupan, dan karir di abad ke-21. Pembelajaran Abad 21 memfokuskan kepada keterampilan berpikir kritis dan berinovasi yang uraiannya meliputi Berpikir Kritis dan Menyelesaikan Masalah (Critical thinking and problem solving), Komunikasi dan Kolaborasi (Communication and collaboration), Kreativitas dan Inovasi (Creativity and innovation) (Bernie Trilling \& Charles Fadel, 2009).

\section{Keterampilan Berpikir Kritis}

Keterampilan berpikir kritis merupakan kemampuan yang sangat diperlukan seseorang agar dapat menghadapi berbagai permasalahan yang dihadapi dalam kehidupan bermasyarakat maupun personal. Facione (2011) menyatakan bahwa berpikir kritis merupakan pengaturan diri dalam memutuskan sesuatu yang menghasilkan interpretasi, analisis, evaluasi, dan inferensi, maupun pemaparan menggunakan suatu bukti, konsep, metodologi, kriteria, atau pertimbangan kontekstual yang menjadi dasar dibuatnya keputusan. Keterampilan berpikir kritis dapat dikembangkan pada peserta didik melalui proses pembelajaran di sekolah.

Berpikir kritis mempunyai peranan penting dalam pembelajaran karena dengan kemampuan berpikir kritis yang memadai, siswa tidak hanya dapat menguasai isi dari setiap mata pelajaran yang dipelajarinya tetapi juga akan dapat mengaplikasikannya dalam kehidupan sehari-hari. Kemampuan berpikir kritis peserta didik dalam pembelajaran IPA sangat diperlukan dalam menghubungkan dan memahami konten materi IPA yang bersifat mikroskopis dan abstrak yang membutuhkan analisis, evaluasi dan interpretasi pikiran peserta didik yang baik (Yustiqvar et al, 2019). Keterampilan berpikir kritis meliputi keterampilan analisis, sintesis, interpretasi, evaluasi, dan membuat asumsi yang membekali peserta didik pada abad 21 (Sendag \& Odabasi, 2009).

\section{Komunikasi dan Kolaborasi}

Keterampilan kedua yang dibutuhkan pada abad 21 yaitu komunikasi dan Kolaborasi. Kemampuan komunikasi mencakup keterampilan dalam menyampaikan pemikiran dengan jelas dan persuasif secara oral maupun tertulis, kemampuan menyampaikan opini dengan kalimat yang jelas, menyampaikan perintah dengan jelas, dan dapat memotivasi orang lain melalui kemampuan berbicara. Kolaborasi dan kerjasama tim dapat dikembangkan melalui pengalaman yang ada di dalam sekolah, antar sekolah, dan di luar sekolah (P21, 2007). Siswa dapat bekerja bersama-sama secara kolaboratif pada tugas berbasis proyek yang autentik dan mengembangkan keterampilannya melalui pembelajaran tutor sebaya dalam kelompok.

Keterampilan

berkolaborasi merupakan hal yang harus diterapkan. Keterampilan komunikasi dan kolaborasi yang efektif disertai dengan keterampilan menggunakan teknologi dan sosial media akan memungkinkan terjadinya kolaborasi dengan kelompok-kelompok internasional.

\section{Kreativitas dan Inovasi}

Keterampilan terakhir yang dibutuhkan pada abad 21 yaitu kreativitas dan inovasi. Kreativitas dapat diartikan sebagai kontruksi multidimensi yang melibatkan variabel kognitif, kepribadian, keluarga, pendidikan, serta sosial budaya (Nakano \& Wechsler, 2018). Kreavitas siswa di dalam pembelajaran dapat terlihat melalui keterampilan berpikir kreatif siswa. Keterampilan berpikir kreatif adalah kemampuan berpikir yang keluar dari pola berpikir biasa, pemikir kreatif mampu membebaskan diri dari pola dominan yang telah disimpan dalam otak (Langrehr dalam Jamaludin, 2010). Berpikir kreatif adalah kemampuan dalam menyelesaikan dan mendapatkan banyak keadaan yang mungkin pemecahan suatu masalah yang menekankan 
pada. Berpikir Kreatif dapat dilihat melalui seberapa banyak tanggapan yang diberikan terhadap suatu persoalan semakin kreatif seseorang.

Ilmu Pengetahuan Alam (IPA) merupakan salah satu mata pelajaran yang mempelajari tentang fenomena alam yang terjadi lingkungan sekitarnya. Proses pembelajaran IPA yang ideal merupakan proses membelajarkan peserta didik untuk memperoleh produk dan proses, yang secara tidak langsung dapat membentuk keterampilan berpikir kreatif peserta didik. Keterampilan ini akan sangat dibutuhkan bagi peserta didik untuk membantu kesuksesannya dimasa yang akan dating.

\section{Pemanfaatan Augmented Reality untuk melatih Keterampilan Abad 21}

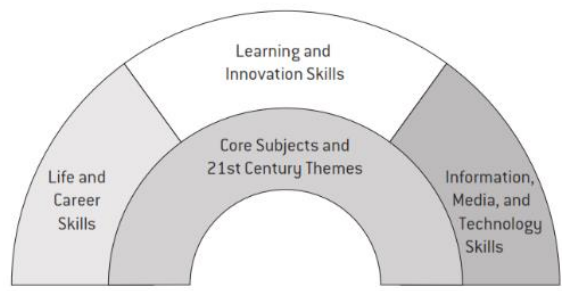

Pembelajaran Abad 21 menekankan subjek pembelajaran terhadap siswa pada keterampilan dalam menggunakan Media, Informasi dan Teknologi; Keterampilan berpikir dan berinovasi serta keterampilan yang dapat digunakan dalam kehidupan dan karir (Bernie Trilling \& Charles Fadel, 2009). Pemanfaatan Augmented Reality dalam pembelajaran dapat digunakan untuk melatih keterampilan siswa di menggunakan Media, Informasi dan Teknologi saat ini. Augmented Reality merupakan aplikasi yang terdapat pada smartphone Andorid dan sedang mengalami perkembangan saat ini. Aplikasi Augmented Reality dimanfaatkan pada pembelajaran IPA oleh beberapa peneliti untuk melatih keterampilan Abad 21 yang menjadi salah satu tuntutan pembelajaran saat ini.

Penelitian yang dilakukan beberapa peneliti saat ini yaitu memanfaatkan Augmented Reality untuk melatih keterampilan berpikir yang meliputi keterampilan berpikir kritis, keterampilan berpikir abstrak, dan kemampuan berpikir kreatif. Penggunaan Augmented Reality yang menarik dan interkatif bagi siswa akan mendorong minat keterlibatan siswa dalam pembelajaran. Keterlibatan siswa dalam pembelajaran menggunakan media Augmented Reality merupakan hal yang perlu dalam melatih kemampuan berpikir tingkat tinggi siswa seperti pemecahan masalah, berpikir kritis atau kreatif serta kemampuan siswa berkolaborasi (Romy Desmara Fendi, et al., 2021). Pemanfaatan Augmented Reality memerlukan aktivitas pembelajaran yang mampu melibatkan siswa untuk berpikir ilmiah dan pengalaman dalam mencari tahu sendiri jawaban dari pertanyaan yang ada (Maryam, et.al., 2020). Aktivitas pembelajaran demikian yang akan membantu Augmented Reality sebagai media dalam melatih keterampilan berpikir abad 21. Augmented Reality sebagai media pembelajaran memerlukan aktivitas pembelajaran yang sesuai dengan karakteristik pembelajaran abad 21 untuk melatih keterampilan abad 21.

\section{Keterampilan Berpikir Kritis}

Augmented reality sebagai media pembelajaran berbentuk teknologi visual yang terdiri dari gambar peristiwa ditambahkan dengan tampilan gambar 2D sampai 3D. Teknologi Augmented Reality mampu merealisasikan dunia virtual ke dunia nyata sehingga penerapan teknologi AR dalam pembelajaran IPA akan mengarahkan siswa untuk menemukan konsep fisika secara mandiri (Luh Devi Herliandry et.al, 2020) (A. Handjoko Permana, et.al., 2019). Akitivas pembelajaran ini mendorong siswa untuk menganalisis konsep fisika secara keseluruhan yang disajikan dalam lembar kerja sehingga melatih keterampilan berpikir kritis siswa (Luh Devi Herliandry et.al, 2020).

Augmented Reality dianggap dapat melatih keterampilan berpikir kritis dikarenakan siswa memerlukan kemampuan berimajinasi dan memahami sebuah gambar yang disebut dengan kemampuan literasi visual (J.N Iqliya dan R. Kustijono, 2019). Literasi Visual adalah kemampuan untuk membangun arti dari gambar. Literasi visual menggunakan keterampilan sebagai kotak peralatan dan merupakan bentuk dari berpikir kritis yang meningkatkan kemampuan intelektual. Hal ini secara tidak langsung 
menyatakan bahwa media augmented reality dapat melatihkan keterampilan berpikir kritis melalui pengembangan literasi visual peserta didik (J.N Iqliya dan R. Kustijono, 2019). Media Augmented Reality memiliki gambar yang berfungsi sebagai media visual sehingga memiliki kaitan dengan literasi visual.

\section{Keterampilan Berpikir Abstrak}

Augmented Reality dimanfaatkan untuk melatih kemampuan literasi Visual. Kemampuan literasi visual merupakan kemampuan yang mengacu pada kemampuan untuk meng interpretasi, mengaitkan dan memaknai informasi yang disampaikan dalam bentuk visual atau gambar (Avgerinou \&Ericson, dalam Santhi Sidhartani, 2016). Berdasarkan, hal tersebut maka Augmented Reality selain dapat digunakan untuk melatih keterampilan berpikir kritis ternyata dapat pula digunakan untuk melatih kemampuan berpikir abstrak. Keterampilan berpikir abstrak merupakan keterampilan mendefinisikan kasus, kejadian atau hal yang belum terjadi, dimana siswa mampu menentukan prediksi, menarik kesimpulan yang tepat dan memecahkan masalah tanpa harus langsung berhadapan dengan hal-hal, kondisi atau kejadian nyata (Wahyuni dkk.,2013). Augmented Reality dapat dimanfaatkan untuk melatih Keterampilan berpikir abstrak karena untuk memahami informasi yang disampaikan oleh media Augmented Reality siswa memerlukan kemampuan siswa didalam berimajinasi dengan objek yang tidak dihadapi secara langsung (Ricki Angga Rizti Yovan dan Abd. Kholiq, 2020). Kemampuan siswa untuk berimajinasi terhadap suatu objek yang tidak dihadapi langsung memerlukan

\section{Keterampilan Berpikir Kreatif}

Augmented Reality dapat dimanfaatkan untuk melatih Keterampilan Berpikir Kreatif (Resti Wulandari dkk, 2020). Augmented Reality sebagai salah satu teknologi yang mulai di terapkan pada bidang pendidikan saat ini merupakan teknologi interaktif yang memungkinkan kita berinteraksi langsung dengan benda-benda virtual di dunia nyata. Penggunaan teknologi inovatif dalam pembelajaran dengan menggabungkan Augmented Reality pada kegiatan belajar sains (Goff, et al., 2018) yang akan berpengaruh terhadap keterampilan berpikir kreatif. Keterampilan berpikir kreatif merupakan sesuatu hal yang dapat dilatih dan dikembangkan secara terus-menerus (De Bono dalam Nurlaila D. dkk., 2016). Penggunaan AR dalam pembelajaran akan membantu guru untuk membangun interaksi dengan peserta didik, karena media yang digunakan oleh guru merupakan pengalaman baru yang diterima oleh pesera didik. Suasana kelas yang menantang, menyenangkan, dan kebebasan siswa dalam beraktivitas dan berinteraksi dengan guru maupun dengan siswa yang lain. Interaksi dalam pembelajaran yang telah tercipta dengan baik akan membantu terbentuknya keterampilan berpikir kreatif peserta (Firdaus, dkk., 2018).

\section{Kesimpulan dan Rekomendasi}

Augmented Reality memiliki manfaat sebagai media pembelajaran interaktif, langsung dan nyata bagi siswa dapat mengajak siswa berimajinas. Media Pembelajaran Augmented Reality mampu meningkatkan minat siswa dalam belajar. Media Pembelajaran Augmented Reality dalam melatih keterampilan berpikir abad 21 bergantung kepada aktivitas pembelajaran yang berlangsung.

Penelitian Pengembangan perangkat pembelajaran pada mata pelajaran IPA harus mampu menyesuaikan dengan perkembangan teknologi yang ada saat ini salah satunya Augmented Reality. Pemanfaatan Augmented Reality dalam pembelajaran IPA perlu dikembangkan degan berbasis pada model pembelajaran yang dapat melatih siswa untuk memiliki keterampilan abad 21

\section{DAFTAR PUSTAKA}

Afissunani. 2014. Multi Marker Augmented. Institut Teknologi Sepuluh Nopember. Jurnal Politeknik Elektronika Institut Teknologi. Kampus ITS, 3(1): 1-29.

Afriyanti,I, dkk. 2018. Pengembangan Literasi Sains Mengacu PISA Melalui Pembelajaran Abad Ke-21 Berbasis Teknologi. PRISMA ,1 : 608-617

Alwiyana Septarini \& Abd. Kholiq . 2021. Pengembangan Media Prest untuk meningkatkan Keterampilan Berpikir Kritis Peserta Didik SMA pada Materi Momentum dan Impuls. IPF : Inovasi Pendidikan Fisika, $10(1): 32-38$ 
Azuma, R. T. 1997. A Survey of Augmented Reality. Presence: Teleoperators and Virtual Environments 6 (4): 355-385

Dewi, Synthia; Sisca Mariam \& Jajang Bayu Kelana. 2019. Meningkatkan Kemampuan Berpikir Kreatif IPA Siswa Sekolah Dasar menggunakan Model Contexual Teaching And Learning. Journal of Elementary Education, 2 (6): 235-239

Ennis, R. H. 1985. Goals for a critical thinking curriculum. Alexandria: ASCD.

Firdaus, H. M., Widodo, A., \& Rochintaniawati, D. 2018. Analisis Kemampuan Berpikir Kreatif Dan Proses Pengembangan Kemampuan Berpikir Kreatif Siswa SMP Pada Pembelajaran Biologi. Indonesia Jurnal Of Biology Education.1(1): 21-28

Goff, Eric E.; Kelly Lynn Mulvey; Matthew J. Irvin \& Adam Hartstone-Rose. 2018. Applications of Augmented Reality in Informal Science Learning Sites: a Review. Journal Science Education and Technology

Hunter, D.A. 2009. A practical guide to critical thinking, deciding what to do and believe. Hoboken: John Wiley \& Sons, Inc

Ilmawan Mustaqim \& Nanang Kurniawan. 2017. Pengembangan Augmented Reality sebagai Media Pembelajaran Pengenalan Komponen Pneumatik di SMK. Jurnal Pendidikan Teknologi dan Kejuruan, 14 (2) :136-144

Iqliya, J.N \& R. Kustijono. 2019. Keefektifan Media Augmented Reality untuk Melatihkan Keterampilan Berpikir Kritis Siswa. Prosiding Seminar Nasional Fisika (SNF) Unesa, 3: 19-25

Jamaluddin. 2010. Kemampuan Berpikir Kreatif Siswa SD dalam Pembelajaran IPA. Jurnal Ilmu Pendidikan, 17 (3): 202-209

Johnson, E. B. 2011. CTL. Bandung : Kaifa.

Herliandry, Luh Devi; Heru Kuswanto \& Wahyu Hidayatulloh. 2020. Improve Critical Thinking Ability Through Augmented Reality Assisted Worksheet. Advances in Social
Science, Education and Humanities Research, $541: 470-475$

M. Fadlillah. 2017. Aliran Progresivisme dalam Pendidikan di Indonesia. Jurnal Dimensi Pendidikan dan Pembelajaran, 5 (1) : 17-24

Nurlaila, D.; Muh. Tawil \& Abdul Haris. 2016. Analisis Keterampilan Berpikir Kreatif Fisika Pada Peserta Didik Kelas XI IPAI SMA Negeri 2 Bua Ponrang. Jurnal Pendidikan Fisika Universitas Muhammadiyah Makassar, 4 (1): 127-144

Partnership for 21st Century Skills. 2009. P21 Framework Definitions. Washington, DC: Partnership for 21st Century Skills

Santi Sidhartani. 2016. Literasi Visual sebagai Dasar Pemaknaan dalam Apresiasi dan Proses Kreasi Visual. Jurnal Desain, 3 (3): 155-163

Sendag, S., \& Odabasi, H. F. 2009. Effects of online problem based learning course on content knowledge acquisition and critical thinking skills. Computers \& Education, 53 : 132-141.

Trilling, Bernie \& Fadel,Charles. 2009. 21 st Century skills: Learning in a Web 2.0 World. Solution Tree Press

Wahyuni, Sawitri Epi; Suciati Sudarisman \& Puguh Karyanto. 2013. Pembelajaran Biologi Model POE melalui Laboratorium Riil dan Laboratorium Virtual Ditinjau dari Aktivitas Belajar dan Kemampuan Berpikir Abstrak. BIOEDUKASI Jurnal Pendidikan Biologi, 6 (1): 63-78

Wulandari, Resti; Ari Widodo \& Diana Rochintaniawati. 2020. Penggunaan Aplikasi Augmented Reality Untuk Memfasilitasi Penguasaan Konsep Dan Keterampilan Berpikir Kreatif Peserta Didik. Jurnal Pendidikan Biologi, 11 (2): 59-69

Yovan, Ricki Angga Rizti \& Abd. Kholiq. 2020. Pengembangan Media Augmented Reality untuk Melatih Keterampilan Berpikir Abstrak Siswa SMA pada Materi Medan Magnet. PENDIPA Journal of Science Education, 6 (1): 80-87 